\title{
Monitoring of irritant gas using a whole-cell-based sensor system
}

\author{
U. Bohrn ${ }^{\text {a,b,c,* }, \text { E. Stütz }}{ }^{\text {a }}$ K. Fuchs ${ }^{\text {a }}$, M. Fleischer ${ }^{\text {a }}$, M.J. Schöning ${ }^{b}$, P. Wagner ${ }^{c}$ \\ a Corporate Research E Technologies, Siemens AG, Otto-Hahn-Ring 6, 81739 Munich, Germany \\ ${ }^{\mathrm{b}}$ Institute of Nano- and Biotechnologies, Aachen University of Applied Sciences, Heinrich-Mussmann-Straße 1, 52428 Jülich, Germany \\ ${ }^{\mathrm{c}}$ Institute for Materials Research (IMO/IMOMEC), University Hasselt, Wetenschapspark 1, 3590 Diepenbeek, Belgium
}

\section{A R T I C L E I N F O}

\section{Article history:}

Available online 8 June 2012

\section{Keywords:}

Cell-based gas biosensor

Whole-cell sensor

A549

RPMI 2650

Respiration

Acidification

Impedance

Mid infrared spectroscopy

\begin{abstract}
A B S T R A C T
Cell-based sensors for the detection of gases have long been underrepresented, due to the cellular requirement of being cultured in a liquid environment. In this work we established a cell-based gas biosensor for the detection of toxic substances in air, by adapting a commercial sensor chip (Bionas ${ }^{\circledR}$ ), previously used for the measurement of pollutants in liquids. Cells of the respiratory tract (A549, RPMI 2650, V79), which survive at a gas phase in a natural context, are used as biological receptors. The physiological cell parameters acidification, respiration and morphology are continuously monitored in parallel. Ammonia was used as a highly water-soluble model gas to test the feasibility of the sensor system. Infrared measurements confirmed the sufficiency of the medium draining method. This sensor system provides a basis for many sensor applications such as environmental monitoring, building technology and public security.
\end{abstract}

(c) 2012 Elsevier B.V. All rights reserved.

\section{Introduction}

Due to excessive air pollution millions of people today face adverse health effects [1]. The medical importance of environmental gas toxicity monitoring is by now recognized as an important area and much research has been focused on the development of suitable gas-sensitive materials for continuous monitoring and setting off alarms for hazardous chemical vapours present beyond specified levels [2]. Reliable networks of environmental monitoring stations determining the local pollution have been formed over the past decades. However, these devices are often very cost intensive using bulky optical instruments [3]. In other approaches, air samples must be collected on-site [4] and afterwards transferred to a central laboratory, as air measurements are regularly required in selected spaces such as homes, schools, public buildings, town halls, guild halls and kindergartens, to name but a few $[5,6]$. European regulatory administrations focused their activities to assess health risks of indoor-originated chemical pollutants and to provide recommendations on potential exposure limits [7]. Expensive devices like liquid chromatography or gas chromatography are used for the evaluation of indoor air samples, a process, which is rather time-consuming. To overcome these obstacles,

\footnotetext{
* Corresponding author at: Corporate Research \& Technologies, Siemens AG, OttoHahn-Ring 6, 81739 Munich, Germany. Tel.: +49 89636 43592; fax: +498963646881 .

E-mail addresses: ulrichbohrn@hotmail.com, ulrich.bohrn.ext@siemens.com (U. Bohrn).
}

air quality monitoring using various types of sensor systems like semiconducting $\mathrm{SnO}_{2}$ sensors [8], have emerged. This type of environmental monitoring was mainly a topic for solid-state [9-12] and optical sensors $[13,14]$, whereas biosensors were systematically underrepresented [15].

Cell-based sensors represent a subclass of sensor technology systems with an overwhelming development for the measurement of substances in liquid environments over the last two decades. Cell-based assays are currently considered central to toxicity testing and environmental exposure testing [16-19]. One of the main advantages of cell-based approaches is their possibility to detect not only specific substances but to supply functional information, i.e. information about general cytotoxicity. Up to now, sensors incorporating living cells face the drawback of a steady and high risk of contamination and cell death, caused by changes in the cellular environment. Therefore, toxicologic studies of adverse effects induced by inhaled chemicals are technically challenging and enormous effort has to be made to keep the environment of the sensor as constant as possible regarding factors, like $\mathrm{CO}_{2}$ content, humidity, osmolarity, temperature and mechanic stress $[1,20]$.

Several in vitro methods for gas exposure of mammalian cells already exist $[21,22]$. All of them quantify the amount of toxic effect using common cell culture endpoint assays [23], which are invasive and destructive against target cells. Endpoint assays do not allow a monitoring of a dynamic process in real time [24]. Recent methodological and technical breakthroughs [25-27] of in vitro methods have the potential to fulfill the essential requirements of toxicity testing for airborne chemicals [1] and compared to animal models, cell-based assays raise less ethical concerns. 


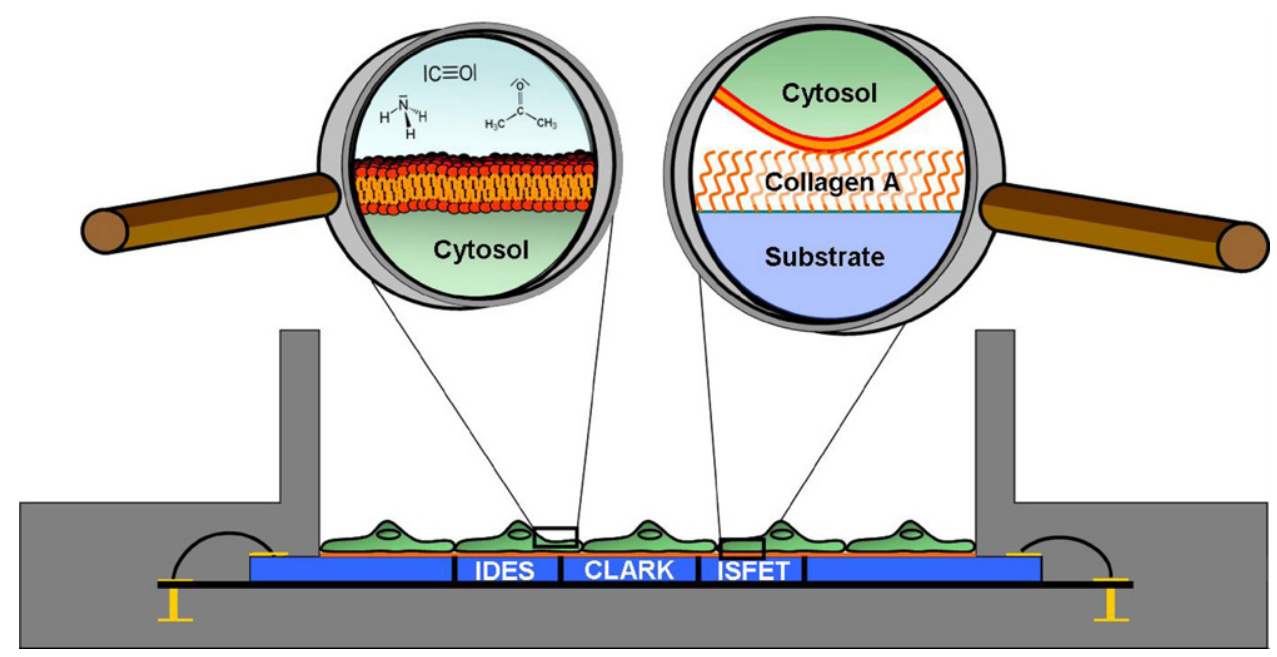

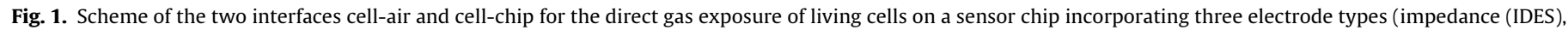
oxygen consumption (CLARK), acidification (ISFET)).

Ammonia $\left(\mathrm{NH}_{3}\right)$ is a colourless toxic gas with a pungent smell, responsible for industrial pollution (threshold limit value (TLV): $25 \mathrm{ppm}$ ) [28]. Ammonia is a widely used hazardous chemical, a usual component of household cleaning products [29] and therefore it is in the focus of gas sensor technologies [30] and risk assessment studies [7]. Gases with high water solubility, like ammonia, formaldehyde and hydrogen halides are resorbed in the upper respiratory tract of the human body, such as nose, pharynx and trachea, [31] and can cause irritation and chemical burn. The cytotoxic effects of ammonia have been known for a long time [32]. Total concentrations of ammonia and ammonium as low as 2-3 mM have been reported to reduce cell growth considerably [33]. Further reported effects of elevated ammonia or ammonium concentrations relate to cellular energy metabolism as ammonia is supposed to reduce metabolic efficiency by forcing excretion of potentially valuable intermediate metabolites (e.g., alanine) in order to achieve ammonia detoxification. Ammonia or ammonium can either perturb the intracellular or intraorganelle $\mathrm{pH}$ and electrochemical gradients, or directly interact with enzymes. $\mathrm{NH}_{3}$ in the unprotonated state is a small, uncharged, lipophilic molecule, which readily diffuses across cellular membranes [34,35]. The diffusion will follow the gradient of the chemical potential of $\mathrm{NH}_{3}$, which can be approximated by the gradient of the partial pressure of $\mathrm{NH}_{3}$. Only a small percentage of $\mathrm{NH}_{3}$ that is present in the extra- and intracellular aqueous phases will diffuse across the membranes, thus rapidly equilibrating any transmembrane gradient of $\mathrm{NH}_{3}$. The $\mathrm{pH}$ equilibrium will be reconstituted immediately as protonation is extremely fast. In a compartment with low $\mathrm{pH}$, the partial pressure of $\mathrm{NH}_{3}$ is lower, leading to a constant flow of $\mathrm{NH}_{3}$ across the membrane into the compartment, until equilibrium is attained, i.e., the pH rises [33]. The functioning of organelles with low internal $\mathrm{pH}$, such as lysosomes can be seriously disturbed in the presence of ammonia. Diffusion of the protonated form, $\mathrm{NH}_{4}{ }^{+}$, across cellular membranes is extremely slow. Values for the diffusion rate range from four to five orders of magnitude below those of unprotonated ammonia [35]. $\mathrm{NH}_{4}{ }^{+}$can be transported actively across the cell membrane by specific transport proteins such as the $\mathrm{Na}^{+} \mathrm{K}^{+}$-ATPase [36], by facilitated diffusion by means of the $\mathrm{Na}^{+} \mathrm{K}^{+} 2 \mathrm{Cl}^{-}$-cotransporter, and possibly by the $\mathrm{Na}^{+} / \mathrm{H}^{+}$-exchanger. $\mathrm{NH}_{4}{ }^{+}$is interacting with the binding site for $\mathrm{K}^{+}$, as hydrated $\mathrm{NH}_{4}{ }^{+}$ has roughly the same ionic radius as $\mathrm{K}^{+}$. $\mathrm{NH}_{4}{ }^{+}$is in competition with $\mathrm{K}^{+}$and perturbs the transmembrane transport of the latter [37]. This may have important constraints for the ion gradients over the cell membrane.
Ammonia interacts with the $\alpha$-ketogluterate within the Krebs Cycle and interrupts the ATP (adenosine triphosphate) production in the mitochondria [38]. This also leads to an impairment of the mitochondrial function [39]. Ammonia influences cellular energy metabolism by influencing the relative amount of carbohydrate and glutamine taken up, and by altering the utilization of the different metabolic pathways, including glycolysis, the citric acid cycle, pentose-phosphate pathway and the different mechanisms of glutamine degradation. This influence could be due to interactions with regulatory key enzymes of the different pathways.

The critical ammonia concentration appears to be strongly dependent on the cell line and cultivation conditions. The cellular mechanisms of ammonia or ammonium toxicity are still controversial subjects. Ammonium toxicity has been shown to be more pronounced at higher $\mathrm{pH}$, indicating that unprotonated ammonia $\left(\mathrm{NH}_{3}\right)$ and not ammonium ions $\left(\mathrm{NH}_{4}{ }^{+}\right)$is responsible for the toxic action.

The aim of this work was to use a cell-based sensor in a gaseous environment to measure toxicity of an air/gas-mixture of a highly soluble gas. As a transducer unit we used a commercial sensor chip (Fig. 1), which measures the physiological parameters acidification and respiration and indicates the cellular morphology by impedance recordings. The sensor chip acts as a Petri dish where the cells are constantly fed with nutrition medium via a fully automated on-top perfusion system. Until now, this system was primarily used for the detection of toxic substances in liquid medium. For this work, we adapted the system as reported earlier [40], so that it can be also used for the direct exposition of the mammalian cells with toxic substances in gas phases. A direct air-cell contact was generated by drainage of the liquid medium, thereby eliminating the possibility that gas molecules will be altered before contacting the cells [41]. With this system, we aim to sense toxic effects of gaseous air pollutions on the cellular functions. The effect of pollutant concentration, airflow rate and exposure time was examined [42]. Finally, further modification possibilities and enhancement of stability and reproducibility will be discussed.

\section{Materials and methods}

\subsection{Cell culture}

Three different types of commercially available cell lines were chosen for the following experiments. The human lung alveolar type II cell line A549, the Chinese hamster lung fibroblast cell line 
V79 and the human nasal squamous cell line RPMI 2650 were purchased from the DSMZ (German Collection of Microorganisms and Cells).

A549 and V79 cells were grown in Dulbecco's modified Eagle's medium (DMEM) (Gibco, Darmstadt) supplemented with 10\% heat inactivated fetal calf serum (FCS) (Biochrom, Berlin), penicillin (100 units/ml) (BioWhittaker, Germany), and streptomycin $(100 \mu \mathrm{g} / \mathrm{ml})$ (BioWhittaker, Germany) in a $25 \mathrm{~cm}^{2}$ culture flask in a humidified incubator $\left(5 \% \mathrm{CO}_{2}\right)$ at $37^{\circ} \mathrm{C}$. RPMI 2650 cells were grown in Minimum Essential Medium (MEM) (Gibco, Darmstadt) with the same amount of supplements like DMEM. The media were adjusted to an initial $\mathrm{pH}$ of $7.4\left(25^{\circ} \mathrm{C}\right)$. Cells were cultured until $80-100 \%$ confluency. The cell line was used within 20 passages from the received stock. Grown cells were enzymatically harvested in the incubator within 5 min using trypsin $0.05 \%$ (w/v)/EDTA $0.02 \%$ (w/v) (ethylene diamine tetra acetic acid) (Biochrom, Berlin). This resulted in detachment of the cells from the plastic culture surface. The flask was removed from the incubator and agitated gently to dislodge any cells that may not have detached during trypsinization. To stop the action of trypsin, $5 \mathrm{ml}$ pre-warmed DMEM was added to the flask. Suspended cells were seeded on Metabolic Chips SC 1000 (Bionas ${ }^{\circledR}$ ). Prior to the seeding, the sensor chips were soaked with EtOH $(70 \% \mathrm{w} / \mathrm{v})$ and rinsed with $\mathrm{Ca}^{2+}$ - and $\mathrm{Mg}^{2+}$-free phosphate buffered saline (PBS) (Biochrom, Berlin). The seeding density was 120,000 cells $/ \mathrm{cm}^{2}$ and the well of the sensor chip was filled with $500 \mu \mathrm{l}$ medium. The cells were left to adhere over night on the sensor chip, which was used as a Petri dish. Cells were grown until 100\% confluency on the sensor chip to ensure that the initial impedance would not affect the result of the following gas treatment. Confluency and morphology of the cell layer was controlled by microscopy (SM-LUX HL, Leitz Wetzlar, Germany).

\subsection{Cell adhesion measurement and chip coating}

For the real-time monitoring of the cell proliferation, spreading and adhesion, a solution of suspended cells in a special adhesion medium (carbonate buffer free DMEM, 1 mM Hepes (BioWhittaker, Germany), 10\% FCS, pH 7.4) was transferred into the culture vessel of the cell sensor chip. The cell sensor chips were used in an "open" mode in which the fluidic head of the sensor module was lifted to enable the settlement of the cells on the sensor chip surface. Therefore, only the cell impedance data can be monitored over this time as the respiration and the acidification would need the connection to the reference electrode, which is part of the fluidic head. The whole sensor system was placed inside an incubation hood, which is stable tempered at $37^{\circ} \mathrm{C}$.

The surface of the sensor chip was previously coated with different types of extra-cellular matrix proteins (collagen A, fibronectin) and poly-L-lysine (PLL). Sensor coating was done as follows: the sensor chips were sterilized with $\mathrm{EtOH}(70 \% \mathrm{w} / \mathrm{v})$ and then rinsed twice with PBS. A solution containing collagen A $(100 \mathrm{mg} / \mathrm{ml}$ PBS) (Biochrom, Berlin) was added onto the sensor chip surface, which was subsequently incubated for $30 \mathrm{~min}$ at $37^{\circ} \mathrm{C}$ in the incubator. In case of PLL coating ( $1 \mathrm{mg} / \mathrm{ml} \mathrm{PBS)} \mathrm{(Sigma,} \mathrm{Germany)} \mathrm{and} \mathrm{fibronectin}$ coating ( $1 \mu \mathrm{g} / \mathrm{ml}$ PBS) (Sigma, Germany) the solution was used to cover the chips for $1 \mathrm{~h}$ at room temperature. Afterwards, the coating solution was removed and the chips were rinsed properly with sterile $\mathrm{H}_{2} \mathrm{O}$. All coatings were performed under sterile conditions. The chip vessel opening was covered with a glass slide to avoid evaporation of the liquid and to prevent contaminations of the cell culture. For studying cell adhesion, cells were transferred into the vessel of the cell sensor chip, placed inside an incubation hood $\left(37^{\circ} \mathrm{C}\right)$ and impedance data were recorded every 10 s over a time span of $20 \mathrm{~h}$. The $\mathrm{pH}$ value in the Hepes buffered medium was almost constant and was not reduced more than $0.2 \mathrm{pH}$ units.

\subsection{Measurement of ammonia solved in liquid nutrient medium}

For the measurement of the effects of ammonia on the living cells, the system was used as described previously [43]. In brief, sensor chips with a confluent cell monolayer were placed inside the biomodules inside the six parallel arrangements of the sensor system 2500 (Bionas ${ }^{\circledR}$, Rostock, Germany). The medium was pumped via an autosampler to the biomodules containing the sensor chips. PEEK tubings (Polyetheretherketon; Bionas, Germany) were used for the medium transport due to their gas impermeability.

Each of the six sensor chips is able to measure three cellular parameters in parallel: the cell morphology via an impedance electrode, the cellular respiration via two Clark-type electrodes, and the cellular acidification via five $\mathrm{pH}$-sensitive field-effect transistor (FET) electrodes [44,45]. Stop/go intervals of 3 min each were chosen to generate one data point per cycle in the normalized diagram (acidification rate and respiration rate, respectively, were recorded during the stop phase; 1 data point $/ 6 \mathrm{~min})$. The data were normalized to a $100 \%$ value $1 \mathrm{~h}$ prior to the exposure phase to simplify the comparison of the untreated and the exposed cell sensor chips. After a time period of $3 \mathrm{~h}$ (conditioning phase) with untreated running medium (carbonate buffer free DMEM, 1\% Hepes, 1\% FCS), ammonia (Merck KGaA, Darmstadt, Germany) solved in running medium was added for another $3 \mathrm{~h}$ (exposure phase). Ammonia solutions were prepared by adding the appropriate amount of concentrated ammonia solution to the running medium. The $\mathrm{pH}$ values of ammonia solved in liquid running medium are shown in Table 1.

In aqueous solution ammonia and ammonium are linked in a $\mathrm{pH}$ dependent equilibrium according to the following equation:

$\mathrm{pH}=\mathrm{p} K+\log \frac{\left[\mathrm{NH}_{3}\right]}{\left[\mathrm{NH}_{4}{ }^{+}\right]}$

with the $\mathrm{pK}$ having a value of 9.3 at $37^{\circ} \mathrm{C}$. The protonation and deprotonation reactions are extremely fast thus ammonia, ammonium and the protons can be considered in equilibrium at any time and at any place. At the physiological $\mathrm{pH}$ of $7.1-7.5$, only about $1 \%$ of the total concentration of ammonia and ammonium is present as $\mathrm{NH}_{3}$, the rest being $\mathrm{NH}_{4}^{+}$[33].

The experiments were terminated by addition of $0.2 \%$ Triton $\mathrm{X}$ 100 containing running medium (termination phase) for another $2 \mathrm{~h}$. The detergent destroys the lipid bilayer membrane of the cells and therefore kills them. The data recorded at this phase represent the state where there is no more adhesion and no more respiration or cell metabolism any more. Before and after each run, the whole fluidic system was cleaned and disinfected with $70 \%$ ethanol and $\mathrm{H}_{2} \mathrm{O}$.

For evaluation of the recoverability of the measurement system and for the reproducibility of the signals within one experiment run, the cells were exposed consecutive with ammonia solution for $3 \mathrm{~h}$ intermitted by a break of additional $3 \mathrm{~h}$ (see Fig. 5). These experiments were also followed by a recovery phase and a termination phase with Triton X-100 at the end.

\subsection{Measurement of ammonia in a gaseous phase}

The gas exposure was performed as described previously in detail [40]. The cell-covered sensor chips were placed inside the

Table 1

$\mathrm{pH}$ values of the ammonia dilutions in Hepes-buffered running medium.

\begin{tabular}{cl}
\hline $\mathrm{NH}_{3}$ concentration & $\mathrm{pH}\left(23^{\circ} \mathrm{C}\right)$ \\
\hline $0 \mathrm{ppm}(=0 \mathrm{mM})$ & 7.31 \\
$50 \mathrm{ppm}(=2.7 \mathrm{mM})$ & 7.33 \\
$250 \mathrm{ppm}(=13.4 \mathrm{mM})$ & 7.33 \\
$500 \mathrm{ppm}(=26.7 \mathrm{mM})$ & 7.34 \\
\hline
\end{tabular}


biomodules of the analyzing system and operated in an alternating stop/go modus ( $3 \mathrm{~min} / 3 \mathrm{~min}$ ) in liquid medium, using a flow rate of $56 \mu \mathrm{l} / \mathrm{min}$ in the go-phase. Immediately before the gas exposure, pumps were stopped to prevent further transport of the liquid medium to the cells. The liquid medium was sucked off completely from the cell monolayer on the chip with a peristaltic pumping system to ensure its full contact with the gas phase. A T-shaped device was plugged on the culture vessel of the sensor chip, which guides the test air over the cells (see also Ref. [46]). The carrier gas was composed of $80 \% \mathrm{~N}_{2}$ and $20 \% \mathrm{O}_{2}$ carrier gas (synthetic air), and supplemented with $\mathrm{NH}_{3}$ gas (Linde, Munich, Germany) to generate the desired concentration of $20-66 \mathrm{ppm} \mathrm{NH}_{3}$. Parts of the carrier gas were humidified at room temperature by using a water bubbler. The gas flow was controlled by mass flow controllers (MFCs). Gas flow rates of 300,500 and $1000 \mathrm{ml} / \mathrm{min}$ were used for the exposure of the cells. A scheme of the whole exposure setup was published earlier [40,47]. After an exposure duration of about $10 \mathrm{~min}$, the cells were cautiously again covered with pre-warmed $\left(37^{\circ} \mathrm{C}\right)$ running medium. The perfusion head was placed inside the chip vessel and the stop/go modus kept on pumping fresh running medium over the cells. The experiment was conducted for at least two more hours with medium flow lasting until the measurement was stopped. A control cell sensor chip was continuously supplied with running medium without gas exposure (CTRL). Control air exposure measurements were done by exposing the cells on the chip with clean, humidified synthetic air $\left(80 \% \mathrm{~N}_{2}, 20 \% \mathrm{O}_{2}, 70 \%\right.$ r.h.). The setup parameters (gas concentration, gas flow, exposure time) were changed to investigate the influence of the several factors. Different cell lines were used in order to identify cells, which react in a most sensitive mode towards ammonia gas.

\subsection{MIR measurements}

Metabolic chips containing a monolayer of V79 cells were used for the spectroscopic investigations to verify the complete removal of cell culture medium during gas exposure. The Middle InfraRed (MIR) measurements were done using a Bruker (Ettlingen, Germany) IFS 66v FT-IR spectrometer. This spectrometer allows high resolution spectroscopic and non destructive measurements by different operating modes. The measurements of the cell - covered chips were carried out in Diffuse Reflectance Infrared Fourier Transform Spectroscopy (DRIFTS), where a sample is placed in the middle of the sample chamber. The beam of the MIR light source (HeNe-Laser) is directed to the middle of the sample surface. Parts of the wavelengths that were directed on it are absorbed, the rest is diffusely reflected, collected by concave reflectors and detected (MCT HgCdTe detector, cooled by liquid nitrogen). By the principle of a Fourier transformation spectrometer, the comparison of the detected signal and the original source beam results in a spectrum of the sample. Three types of sensors were compared: (i) sensor chips with a V79 cell monolayer covered with $200 \mu$ l nutrient medium (average medium height $=2.8 \mathrm{~mm}$ ); (ii) sensor chips with a V79 cell monolayer after the medium was totally removed and dried in a nitrogen flow ( $1 \mathrm{l} / \mathrm{min}$ ) for $100 \mathrm{~min}$; (iii) sensor chips with
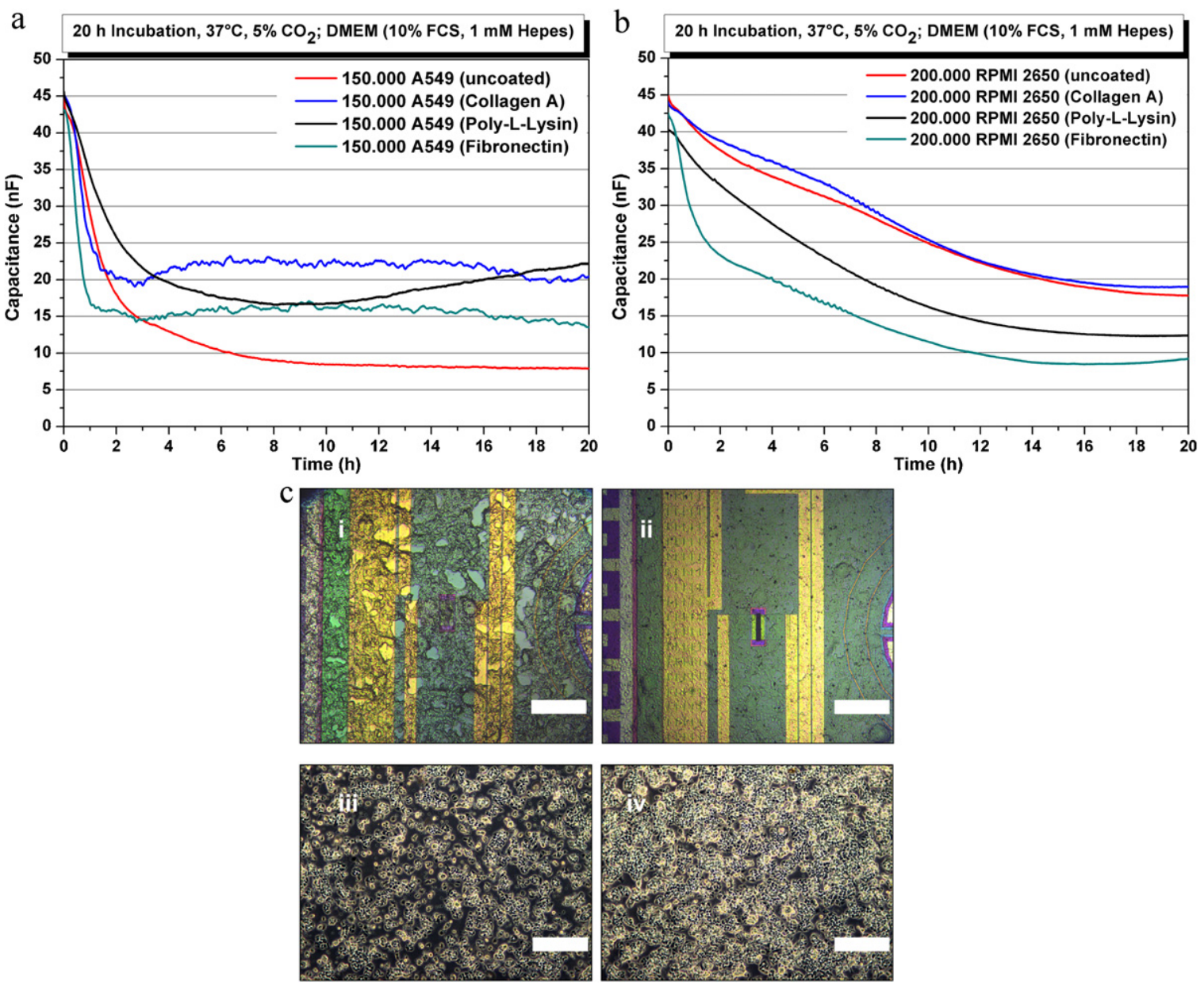

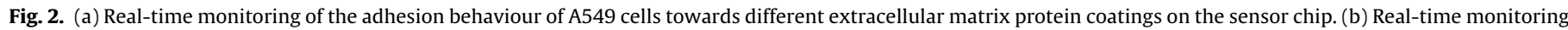

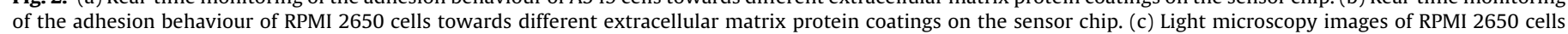
$(200,000)$ on the sensor chip surface and on glas slides without (i and iii) and with (ii and iv) fibronectin coating, scale bar size: $200 \mu \mathrm{m}$. 
a V79 cell monolayer immediately after the medium was drained off. The difference in the MIR signal pattern of a cell monolayer covered with aqueous nutrition media and a cell monolayer extensively dried in a nitrogen flow for 100 min were compared with the signals of a cell monolayer directly after the draining of the nutrient media with the peristaltic pump.

\section{Results and discussion}

\subsection{Results of cell adhesion measurements}

Impedance measurements are widespread for the analysis of cell adhesion towards a specific substrate $[48,49]$. As the cells spread, they alter the effective area available for current flow, causing a decrease in the capacitance as shown in Fig. 2a. A capacitance of about $40 \mathrm{nF}$ corresponds to a cell-free impedance sensor surface covered in liquid running medium whereas capacitance values of about $5-15 \mathrm{nF}$ are generated by the formation of a confluent cell monolayer. The drop in the capacitance within the first 2-4h (Fig. 2b) is caused by the settlement of the cells according to Stoke's law. Depending on the target, different ways of adhesion enhancement can be performed. Cell-based assays in general try to rebuild the in vivo situation as well as possible and therefore use extracellular matrix proteins for the assistance of the adhesion. High impedance values - represented as low capacitance values in the diagram - indicate a strong cell-surface contact accompanied by tight cell-cell junctions [50]. Here the cells block the current path through the cell culture medium. It is known that there is a difference in the adhesion strength of different cell lines. To figure out which cell line generates the highest impedance and therefore is best suited for further experiments, adhesion experiments were performed. Cells were seeded on sensor chips with different surface coatings. Over a time scale of $20 \mathrm{~h}$, the cells settled down on the chip surface and formed a monolayer. Each cell line shows a specific preference of one of the tested ECM proteins (see Fig. 2a-c).

The adhesion curves of V79 cells are already published elsewhere [40]. In the case of A549 cells on a sensor chip with protein coating - surprisingly - the signal stability is lower and therefore, the capacitance values are higher even after several hours of settlement (see Fig. 2a). The nasal cell line RPMI 2650 is currently used as a model for nasal exposure studies [51]. This cell line normally tends to form dome-like clusters on untreated 2D substrates (see Fig. $2 c(i-i v))$. This is undesired in the case of the measurements performed here, where the pre-existence of a stable monolayer is required. The cell adhesion measurements determine lowest capacitance values with a prior fibronectin coating of the substrate (Fig. 2b). In addition, fibronectin-coated sensors chips lead to $>95 \%$ confluency of RPMI 2650 cell layer forming a monolayer instead of islets (Fig. 2c). This fibronectin coating, leading to the best results in terms of lowest capacitance values, was used as standard coating in all further ammonia exposure experiments with RPMI 2650.

\subsection{Results of ammonia exposure in liquid medium}

Ammonia was chosen as a model air pollutant as it is a well known cytotoxic substance, which interrupts the cellular ATP production and therefore causes a decrease in the metabolic activity. Prior to the experiments with gaseous ammonia, we tested if the system is also able to react towards ammonia in a liquid solution and whether these results can be compared with those of the gas exposure measurements afterwards. Fig. 3a-i shows the real-time profiles of impedance, cellular respiration and cellular
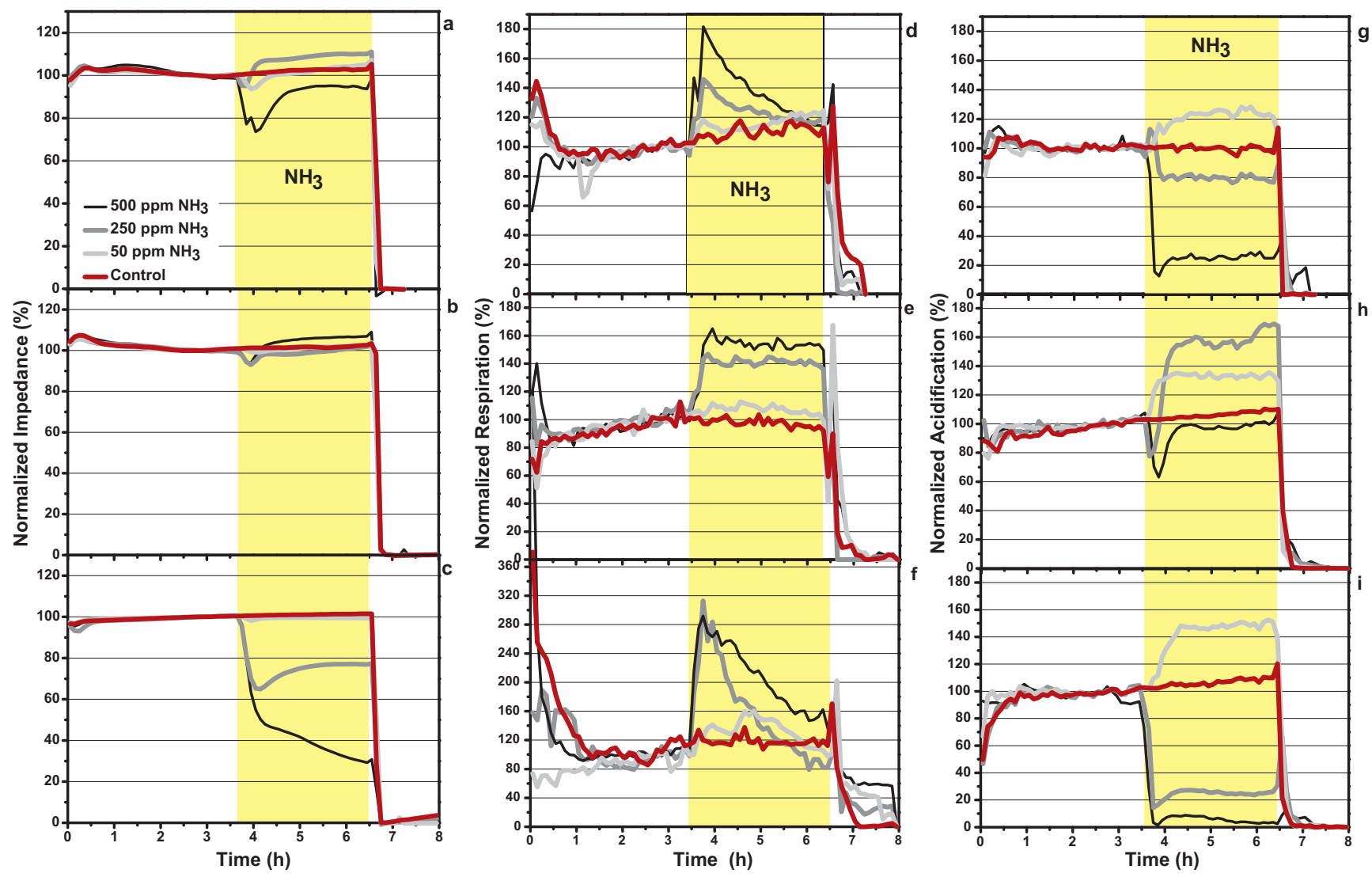

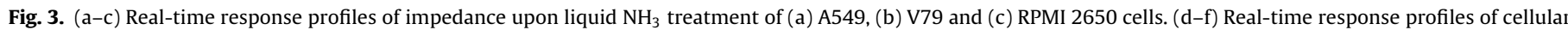

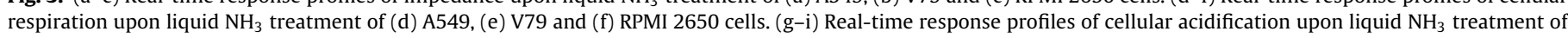
(g) A549, (h) V79 and (i) RPMI 2650 cells. 

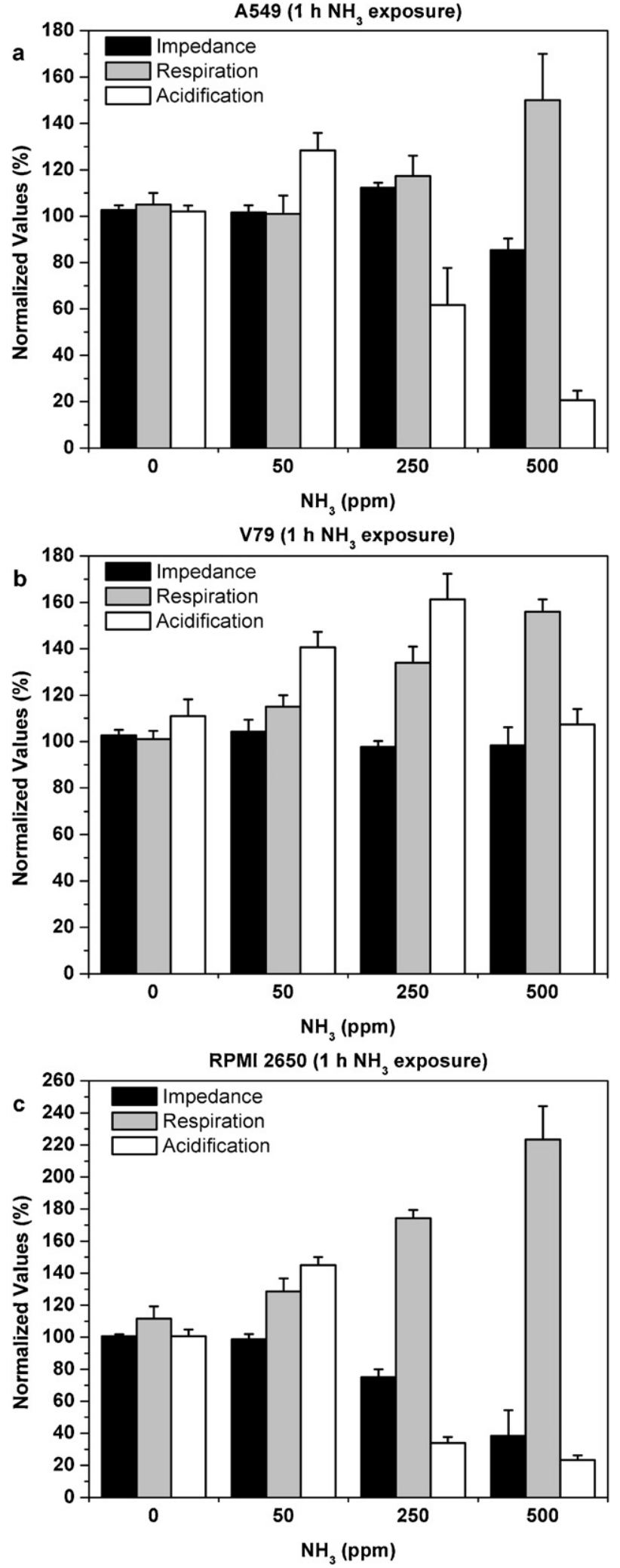

Fig. 4. (a-c) Averaged impedance, respiration and acidification values of (a) A549, (b) V79 and (c) RPMI 2650 cells after treatment with liquid $\mathrm{NH}_{3}$ for $1 \mathrm{~h}$ on $(n=3)$.

acidification of $\mathrm{NH}_{3}$ exposure in liquid phase to V79 cells, A549 cells and RPMI 2650 cells, respectively. Several cell lines of the respiratory tract were chosen to identify the cell lines, which react towards ammonia in the most sensitive way.

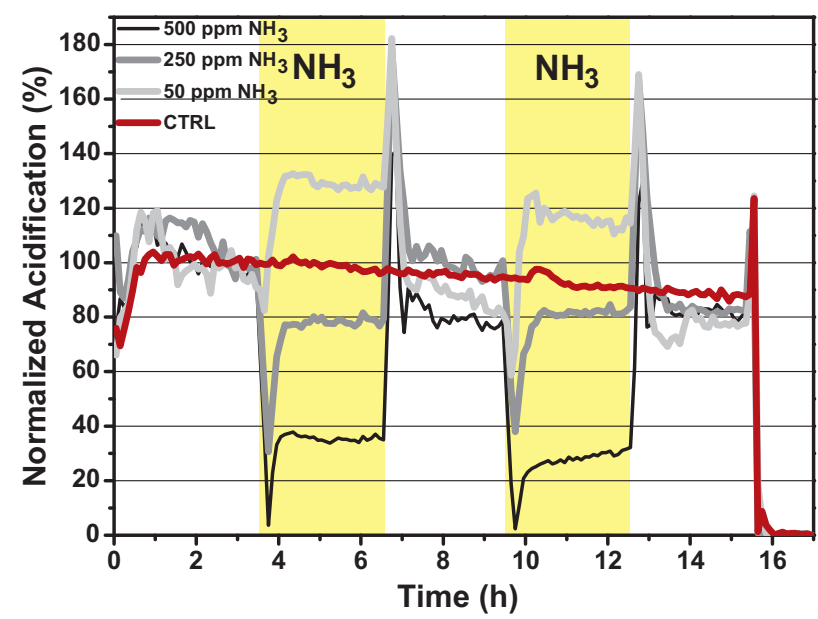

Fig. 5. Real-time response of cellular acidification upon repeated liquid $\mathrm{NH}_{3}$ treatment of A549 cells.

Characteristic and reproducible differences between these different cell lines are observable. All three cell lines react in a dose-dependent way towards the solved ammonia. The ammonia leads to a decrease of the impedance signals immediately after the beginning of exposure (Fig. 3a-c). The cellular respiration increases immediately after the beginning of the exposure to ammonia solution (Fig. 3d-f). Whilst the respiration signal remains increased over time with V79 cells, A549 and RPMI 2650 cells show a decrease of the respiration rate after $\sim 30 \mathrm{~min}$ of ammonia treatment. The acidification rate is also affected immediately. The acidification decreases at high concentrations ( $>250 \mathrm{ppm}$ ) whereas at low concentrations $(<50 \mathrm{ppm})$ an increase is observable. Fig. $4 \mathrm{a}-\mathrm{c}$ shows the differences in the signal changes of the cellular parameters between the investigated cell lines after $1 \mathrm{~h}$ of exposure to ammonia solved in liquid nutrient medium. After $1 \mathrm{~h}$, a concentration-dependent increase in the respiration can be observed for all three cell lines. A549 and RPMI 2650 cells display a dose-dependent reduction of the acidification rate for 250 and $500 \mathrm{ppm} \mathrm{NH}_{3}$ whereas $50 \mathrm{ppm}$ $\mathrm{NH}_{3}$ shows an increase compared with untreated cells $(0 \mathrm{ppm} \mathrm{NH}$, Fig. 4a and c). The reduced metabolism recovers over the experimental time, which is exemplarily shown at the examples of A549 cells in Fig. 5. The sudden increase and collapse of the signals immediately after the end of the ammonia solution exposure is an artifact of the partially changed medium. Within two pumping cycles, the medium over the cells on the chip is completely changed which leads to the stabilized acidification signals. After $3 \mathrm{~h}$ of ammonia exposure, followed by another $3 \mathrm{~h}$ of running medium treatment, the normalized acidification reaches $80-100 \%$ of the normalized value of the control measurement. The opposite trend of respiration and acidification rates during the ammonia exposure indicates that the inhibition of the ATP production via the cellular Krebs Cycle metabolism or the intracellular pH gradient may be partially compensated by the activation of the cellular respiration (oxidative phosphorylation). Compared with the other cell lines tested in this study, RPMI 2650 cells showed the strongest response towards ammonia and is therefore selected as the test cell line for the following gas exposure measurements.

\subsection{Results of ammonia exposure in gas phase}

One goal of this study was to establish a gas exposure system, which is able to detect small amounts of gaseous pollution in an air sample. Therefore, the background signal $\left(0 \mathrm{ppm} \mathrm{NH}_{3}\right)$, which includes the effects of humidified synthetic air exposure with a certain gas flow, should ideally be as low as possible. The exposure to 

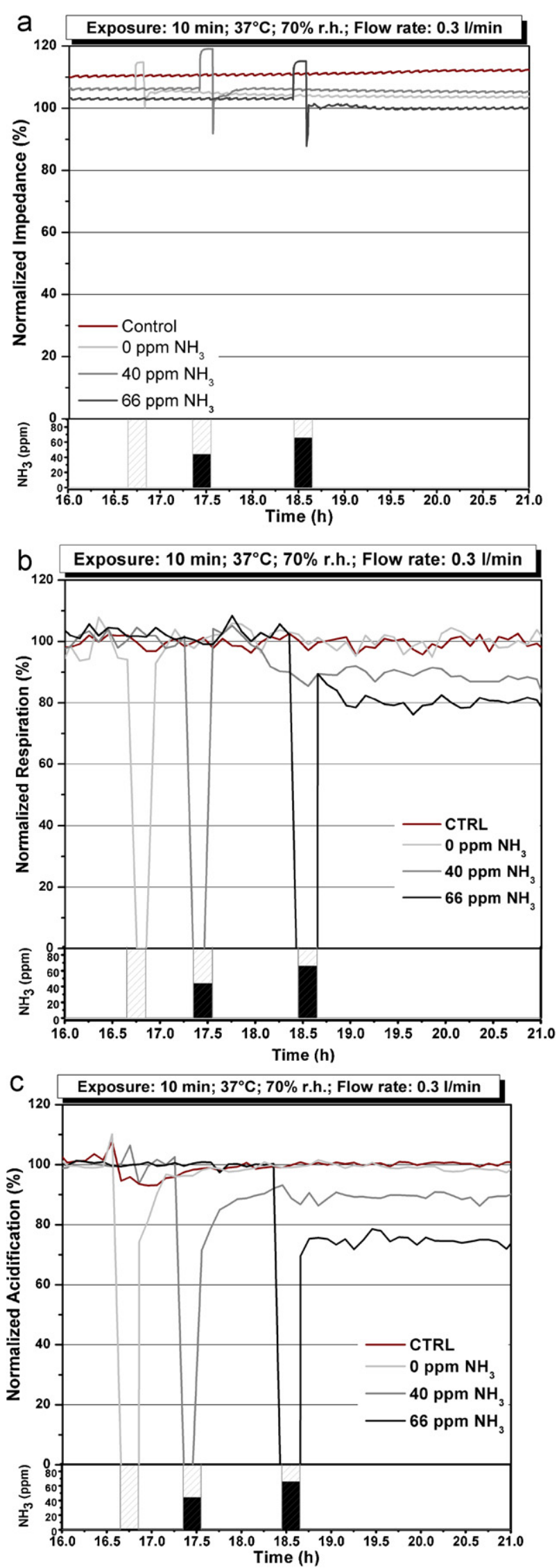

humidified synthetic air also leads to a minor change in the cellular parameters which should be as low as possible to keep the functionality and viability of the cells. Changes might occur due to the exsiccation effect of the gas as well as shear forces on the outer cell membrane which could provoke a lifting-off of the cells. Regarding the quality standards of other experiments, we decided to choose a set of parameters, which leads to a reduction of the background signal of being less than $10 \%$ [52].

The normalized impedance values of the RPMI 2650 cells decrease just in a minor way after the gas exposure (Fig. 6a). The changes during the gas exposure itself occur because of the medium drainage and the therefore changed impedimetric behaviour of the covering species on the sensor surface. The unaffected impedance values indicate that the cell monolayer on the impedance electrode on the sensor chip surface is still confluent and not disrupted by the shear forces of the air flow. Respiration rates of the nasal cells are permanently decreased by ammonia after the gas exposure (Fig. 6b). The drop in the respiration rate (as well as in the acidification rate) is an artifact caused by the disconnection of the reference electrode in the fluid head from a liquid medium. The cell line also reacts towards ammonia diluted in synthetic air with a stable decrease of the acidification rate of about $10 \%$ for $40 \mathrm{ppm} \mathrm{NH}_{3}$ and of about $30 \%$ for $66 \mathrm{ppm} \mathrm{NH}_{3}$ (Fig. 6c), stabilizing approximately 30-60 min after the end of the gas exposure.

It is likely and known from literature that ammonia reacts with $\alpha$-ketoglutarate [39], a component of the Krebs Cycle, and thereby inhibits the ATP production as well as the cellular respiration. In addition, the intracellular $\mathrm{pH}$ gradient is disturbed too by the alkaline ammonia. The direct contact inhibits the possibility of a compensation of energy loss in the cell. In line with this we observed a simultaneous decrease of both the acidification and the respiration rate. The impedance of the cells is not affected in a lasting manner, likely due to the washing-out of ammonia by fresh medium, which floods the sensor chip directly after the gas exposure. One has to keep in mind that the signal reduction has to be always compared to the control measurement of cells exposed to humidified synthetic air.

\subsection{Change of setup parameters}

Important parameters for the dynamic in vitro exposure method are the airflow rate, the pollutant concentration and the duration of the direct exposure. The initial exposure procedure was defined on the basis of control experiments, which were done with humidified synthetic air (data not shown). It turned out that the quality of the results can be optimized with increasing the exposure durations between 5 and $15 \mathrm{~min}$ [38] and with increasing airflow rates in the range between 300 and $1000 \mathrm{ml} / \mathrm{min}$. The flow rates are rather high compared with many other in vitro gas exposure systems [53-55] although similar flow rates of $200 \mathrm{ml} / \mathrm{min}$ [56] and 101/min [57] have been reported too. The main reason for the differences in the flow rates are related to the cultivation method and the exposure duration. Cells grown on a permeable membrane directly at the

Fig. 6. (a) Changes of normalized impedance due to the exposure of RPMI 2650 cells to different concentrations of ammonia gas diluted in synthetic air for $10 \mathrm{~min}$. Grey bars indicate exposure to the carrier gas; black bars indicate the amount of $\mathrm{NH}_{3}$. The measurements were done consecutive on parallel sensor chips. (b) Changes of normalized respiration due to the exposure of RPMI 2650 cells to different concentrations of ammonia gas diluted in synthetic air for $10 \mathrm{~min}$. Grey bars indicate exposure to the carrier gas; black bars indicate the amount of $\mathrm{NH}_{3}$. The measurements were done consecutive on parallel sensor chips. (c) Changes of normalized acidification due to the exposure of RPMI 2650 cells to different concentrations of ammonia gas diluted in synthetic air for $10 \mathrm{~min}$. Grey bars indicate exposure to the carrier gas. The measurements were done consecutive on parallel sensor chips. 


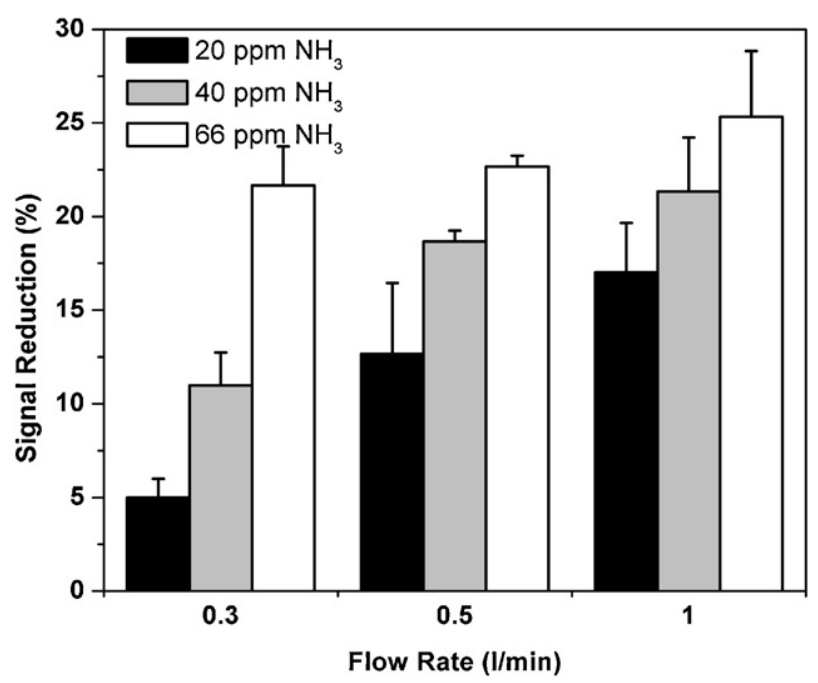

Fig. 7. Influence of $\mathrm{NH}_{3}$-gas flow rates on the acidification rates of RPMI 2650 ( $1 \mathrm{~h}$ after the end of gas exposure) displayed as the relative signal reduction compared to RPMI 2650 cells exposed to humidified synthetic air $(n=3)$.

air-liquid-interface (ALI) are constantly in contact with nutrient medium and therefore are able to survive for a long time at the gas phase. This enable prolonged exposure durations as one limiting factor - the shortage of nutrients - is eliminated. The extended exposure duration enables the user to select reduced flow rates (typically in the range of $5-10 \mathrm{~mL} / \mathrm{min}$ ) to avoid aspiration and drying. In contrast, intermitting methods, like the one presented in this study, have to stop the exposure after short time to supply the cells with liquid nutrient medium.

As shown in Fig. 7, an increase in the $\mathrm{NH}_{3}$ concentration leads to a stronger decrease of the acidification rate (determined $1 \mathrm{~h}$ after the end of the gas exposure). The signal reductions shown in Fig. 7 are the relative signal reductions compared to the cells exposed to humidified air. The exposure to humidified clean air for 10 min with a flow rate in the range of $300-1000 \mathrm{ml} / \mathrm{min}$ has almost no influence on the acidification signals, as the values of the untreated cells $\pm 5 \%$ are reached again within 30-60 min after the gas exposure. The pattern of increasing signal reduction can be observed with different airflow rates. The same concentration of pollution leads to stronger reductions of the acidification rate with an increase of the airflow rate, which can be also observed over different concentrations.

\subsection{Results of MIR measurements}

MIR spectroscopy provides prominent signals in the area of the $\mathrm{H}-\mathrm{O}$ vibration around $1600 \mathrm{~cm}^{-1}$. Therefore we used this technique to check for residual amounts of cell culture medium on top of the cells, since this might inhibit the direct contact of the probe gas with the cell monolayer. $\mathrm{H}-\mathrm{O}$ vibrations can be found in the infrared spectrum in two regions: (a) in the area around $1600 \mathrm{~cm}^{-1}$ (humidity of gas phase) and (b) in the area around $3400 \mathrm{~cm}^{-1}$ ( $\mathrm{H}-\mathrm{O}$ stretching vibration; liquid water). Cells covered with aqueous medium show a strong, noisy water signal in the range of the $\mathrm{H}-\mathrm{O}$ vibration $\left(1600 \mathrm{~cm}^{-1}\right.$; black curve; Fig. 8$)$. It becomes a lot more regular and structured after draining off the media and additional drying with a nitrogen flow for $100 \mathrm{~min}$, though it do not disappear due to $\mathrm{H}-\mathrm{O}$ containing substances being present in the cells themselves (green curve; Fig. 8). MIR measurements of the cell monolayer immediately after the draining of the medium by a peristaltic pump produced a curve shape, which is very similar to the curve of the completely dried cell layer (red curve, Fig. 8). Although the draining method seems to work quite sufficiently, one should not forget that the cells are still covered by a thin layer of fluid,

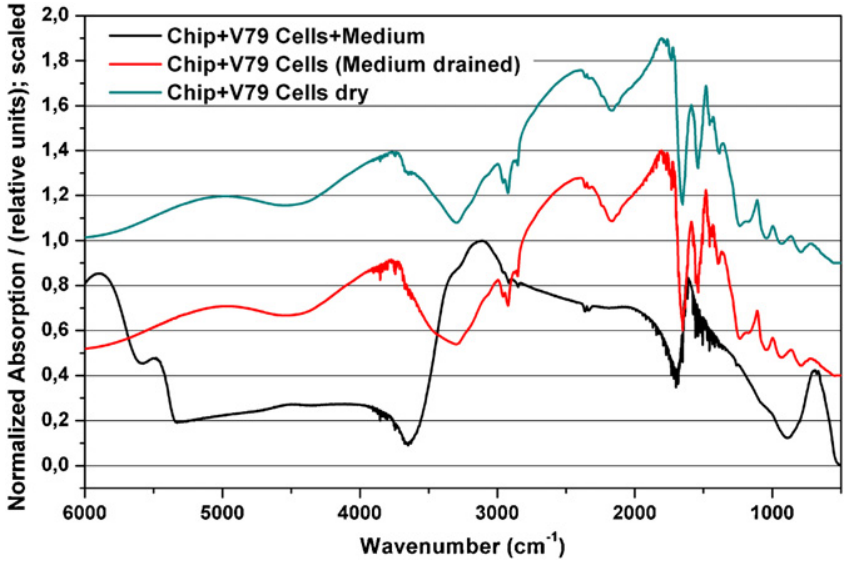

Fig. 8. MIR spectra of V79 cells on a Bionas ${ }^{\circledR}$ sensor chip. The spectrum of the medium drained cell monolayer on the chip (red curve) shows the sufficiency of the draining method as the characteristics of the curve match with the curve representing the completely dried cells (green curve; 100 min $\mathrm{N}_{2}$ ). The spectrum of medium covered cells (black curve; $200 \mu \mathrm{l}$ medium) differ from the drained curve. (For interpretation of the references to colour in this figure legend, the reader is referred to the web version of the article.)

comparable in thickness to the mucus layer overlying the respiratory epithelium [58]. The epithelial lining fluid varies between 0.1 and $20 \mu \mathrm{m}$ in thickness [59], which would correspond to a maximum of $1.43 \mu$ l medium equally distributed over the cells on the sensor chip surface (chip surface area $=70.88 \mathrm{~mm}^{2}$; liquid height $=20 \mu \mathrm{m}$ ). The air/gas-mixture which is pumped over the cells has a temperature of about $27^{\circ} \mathrm{C}$. The temperature of the chip within the Bionas analyzing system is constantly kept at $37^{\circ} \mathrm{C}$. According to this, condensation due to a temperature difference should not occur. A high relative humidity reduces the capability of the air/gas-sample itself to exsiccate the cells to an even higher degree, although a minor degree of evaporation due to the air flow cannot be avoided at all.

\section{Conclusion}

Multiparametric cell-based sensors seem to be a suitable tool for the detection of water-soluble, shown here, as well as waterinsoluble toxic gases [38] in air. We adapted the experimental setup conditions for exposing cells of the respiratory tract to toxic gases in air. The presence of toxic gas leads to the impairment of the living cells, expressed by a sustainable reduction of acidification- and respiration rates that can be monitored within 30-60 min after the gas exposure. The system might be applicable for some extend for the continuous monitoring of ambient air. As an early warning system, the signal generation of this setup will be to slow as modern early warning systems are supposed to react within several seconds or minutes. Although the long reaction time is not competitive to existing early warning systems, one has to keep in mind that extensive concentrations of toxic gases lead not only to an impairment of the cell parameters but even to cell death which can be detected within several minutes after the end of the gas exposure due to the abrupt decrease of both physiological parameters without any recovery. Despite of the use as an early warning tool, long time effects even of low amounts of irritant gases might be detected over an extended time period. Mild parameters ( 10 min exposure, $300-1000 \mathrm{ml} / \mathrm{min}$ flow rate) were chosen for the exposure procedure, so that the exposure to humidified clean air has almost no effect on the generated signals of the cells which enables multiple exposure to unpolluted air without a lost in signal intensity. Repeated exposure of the same cell sensor chip with toxic gases will result in accumulation of the harmful effect as the cellular 
parameters are inhibited more and more after each gas exposure. In the present form, the adapted system is not able to perform measurements automatically as the lifting of the perfusion head, the draining of the medium, the plug-on of the gas exposure device and the reestablishment of the system after the gas exposure has to be done manually by the user. Compared to common solid state gas sensors used for single gases, which have to be maintained only once a year, the described system is laborious and needs higher maintenance (media change, sterilization, cell seeding, change of sensor chip, etc.). However, compared to other in vitro cell-based assays, the sensor system enables the user to gain information very fast, with less laboratory work, a higher possibility for standardization and less man power. In addition, the temporal resolution of the gained results would be drastically increased compared with standard cytotoxicity assays, which typically achieve one data point per $2 \mathrm{~h}$ or more.

Mechanical stability and tolerance towards shear forces produced by the airflow are increased by using extracellular matrix proteins as coatings for the sensor chip surface. MIR spectroscopy turns out to be a sensitive method for the measurement of residual liquids and therefore can be used as a quality control of the draining method. These data gives evidence for possible application of this sensor system for rapid detection of toxic airborne substances, which might not be limited only to gases but potentially includes particular matter too like shown in similar approaches [60]. This sensor system may be used in future in application fields, like environmental monitoring or biomedical applications.

\section{Acknowledgements}

The authors would like to thank Remigiusz Pastusiak for his constant help with the MIR spectroscopy measurements. Furthermore, stimulating scientific discussions with Christian Guijarro are acknowledged.

\section{References}

[1] S. Bakand, A. Hayes, Troubleshooting methods for toxicity testing of airborne chemicals in vitro, Journal of Pharmacological and Toxicological Methods 61 (2010) 76-85.

[2] S. Radhakrishnan, S. Paul, Conducting polypyrrole modified with ferrocene for applications in carbon monoxide sensors, Sensors and Actuators B 125 (2007) 60-65.

[3] Environment S.A. Products (Grenoble, France), http://www.environnementsa.com/index2.php?goto=produits_air (accessed: 21.03.2012).

[4] S. Krol, B. Zabiegała, J. Namiesnik, Monitoring VOCs in atmospheric air II. Sample collection and preparation, Trends in Analytical Chemistry 29 (2010) 1101-1112.

[5] D. Kotzias, Indoor air and human exposure assessment - needs and approaches, Experimental and Toxicologic Pathology 57 (2005) 5-7.

[6] S.V. Krupa, A.H. Legge, Passive sampling of ambient, gaseous air pollutants: an assessment from an ecological perspective, Environmental Pollution 107 (2000) 31-45.

[7] K. Koistinen, D. Koitzias, S. Kephalopoulos, C. Schlitt, P. Carrer, M. Janutunen, S. Kirchner, J. McLaughlin, L. Molhave, E.O. Fernandes, B. Seifert, The INDEX project: executive summary of a European Union project on indoor air pollutants, Allergy 63 (2008) 810-819.

[8] R. Rella, P. Siciliano, S. Capone, M. Epifani, L. Vasanelli, A. Licciulli, Air quality monitoring by means of sol-gel integrated tin oxide thin films, Sensors and Actuators B 58 (1999) 283-288.

9] S. Zampolli, I. Elmi, F. Ahmed, M. Passini, G.C. Cardinali, S. Nicoletti, L. Dori, An electronic nose based on solid state sensor arrays for low-cost indoor air quality monitoring applications, Sensors and Actuators B 101 (2004) 39-46.

[10] T. Tille, Automotive suitability of air quality gas sensors, Procedia Engineering 5 (2010) 5-8.

[11] L. Francioso, A. Forleo, A.M. Taurino, P. Siciliano, L. Lorenzelli, V. Guarnieri, A. Adami, G. Agnusdei, Linear temperature microhotplate gas sensor array for automotive cabin air quality monitoring, Sensors and Actuators B 134 (2008) 660-665.

[12] G.G. Mandayo, J. Herrán, I. Castro-Hurtado, E. Castaño, Performance of a $\mathrm{CO}_{2}$ impedimetric sensor prototype for air quality monitoring, Sensors 11 (2011) 5047-5057.

[13] L.I.B. Silva, T.A.P. Rocha-Santos, A.C. Duarte, Development of a fluorosiloxane polymer-coated optical fibre sensor for detection of organic volatile compounds, Sensors and Actuators B 132 (2008) 280-289.
[14] E. Eltzov, V. Pavluchkov, M. Burstin, R.S. Marks, Creation of a fiber optic based biosensor for air toxicity monitoring, Sensors and Actuators B 155 (2011) 859-867.

[15] K.J.M. Sandström, A.P.F. Turner, Biosensors in air monitoring, Journal of Environmental Monitoring 1 (1999) 293-298.

[16] F. Zucco, I. De Angelis, E. Testai, A. Stammati, Toxicology investigations with cell culture systems: 20 years after, Toxicology in Vitro 18 (2004) 153-163.

[17] N. Bhogal, C. Grindon, R. Combes, M. Balls, Toxicity testing: creating a revolution based on new technologies, Trends in Biotechnology 23 (2005) 299-307.

[18] A. Bentley, A. Atkinson, J. Jezek, D.M. Rawson, Whole cell biosensors-electrochemical and optical approaches to ecotoxicity testing Toxicology in Vitro 15 (2001) 469-475.

[19] Regulation (EC) No 1907/2006 of the European Parliament and of the Council available online: http://eur-lex.europa.eu/LexUriServ LexUriServ.do?uri=OJ:L:2006:396:0001:0849:EN:PDF; (accessed: 21.03.2012)

[20] M. Bäcker, S. Beging, M. Biselli, A. Poghossian, J. Wang, W. Zang, P. Wagner, M.J. Schöning, Concept for a solid-state multi-parameter sensor system for cellculture monitoring, Electrochimica Acta 54 (2009) 6107-6112.

[21] J.W. Knebel, D. Ritter, M. Aufderheide, Development of an in vitro system for studying effects of native and photochemically transformed gaseous compounds using an air:liquid culture technique, Toxicology Letters 96-97 (96) (1998) 1-11.

[22] M. Aufderheide, Direct exposure methods for testing native atmospheres, Experimental and Toxicologic Pathology 57 (2005) 213-226.

[23] R. Dragone, C. Frazzoli, C. Grappelli, L. Campanella, A new respirometric endpoint-based biosensor to assess the relative toxicity of chemicals on immobilized human cells, Ecotoxicology and Environmental Safety 72 (2009) 273-279.

[24] E. Primiceri, M.S. Chiriacò, E. D’Amone, E. Urso, R.E. Ionescu, A. Rizzello, M. Maffia, R. Cingolani, R. Rinaldi, R. Maruccio, Real-time monitoring of coppe ions-induced cytotoxicity by EIS cell chips, Biosensors and Bioelectronics 25 (2010) 2711-2716.

[25] S. Diabate, S. Mulhopt, H.R. Paur, H.F. Krug, Pro-inflammatory effects in lung cells after exposure to fly ash aerosol via the atmosphere or the liquid phase The Annals of Occupational Hygiene 46 (Suppl. 1) (2002) 382-385.

[26] D. Klestadt, P. Lava-Gilly, J. Falla, Ozone-mediated cytotoxicity after shortterm exposure and its relation to the production of cellular metabolites $\left(\mathrm{NO}, \mathrm{H}_{2} \mathrm{O}_{2}\right)$ Cell Biology and Toxicology 18 (2002) 259-269.

[27] F. Lestari, B. Markovic, A.R. Green, G. Chattopadhyay, A.J. Hayes, Comparative assessment of three in vitro exposure methods for combustion toxicity, Journal of Applied Toxicology 26 (2006) 99-114.

[28] P.E. Rosenfeld, L. Feng, Appendix F - ACGIH Threshold Limit Value (TLV), Risks of Hazardous Wastes (2011) 341-354.

[29] M.J. Fedoruk, R. Bronstein, B.D. Kerger, Ammonia exposure and hazard assess ment for selected household cleaning product uses, Journal of Exposure Analysis and Environmental Epidemiology 15 (2005) 534-544.

[30] B. Timmer, W. Olthuis, A. van den Berg, Ammonia sensors and their applications - a review, Sensors and Actuators B 107 (2005) 666-677.

[31] A. Steimer, E. Haltner, C.M. Lehr, Cell culture models of the respiratory tract relevant to pulmonary drug delivery, Journal of Aerosol Medicine and Pulmonary Drug Delivery 18 (2) (2005) 137-182.

[32] M. Tsujii, S. Kawano, S. Tsuji, H. Fusamoto, T. Kamada, N. Sato, Mechanism of gastric mucosal damage induced by ammonia, Gastroenterology 102 (6)(1992) 1881-1888.

[33] M. Schneider, I.W. Marison, U. von Stockar, The importance of ammonia in cell culture, Journal of Biotechnology 46 (1996) 161-185.

[34] W.F. Boron, P. De Weer, Intracellular pH transients in squid giant axons caused by $\mathrm{CO}_{2}, \mathrm{NH}_{3}$ and metabolic inhibitors, Journal of General Physiology 67 (1976) 91-112.

[35] M.A. Knepper, R. Packer, D.W. Good, Ammonium transport in the kidney, Physiological Reviews 69 (1989) 179-249.

36] D. Kikeri, A. Sun, M.L. Zeidel, S.C. Herbert, Cell membranes impermeable to $\mathrm{NH}_{3}$ Nature 229 (1989) 478-480.

[37] S.M. Wall, L.M. Koger, $\mathrm{NH}_{4}{ }^{+}$-Transport mediated by $\mathrm{Na}^{+}-\mathrm{K}^{+}$-ATPase in rat inner meduallary duct, American Journal of Physiology: Renal, Fluid and Electrolyte Physiology 36 (1994) F660-F670.

[38] S. Velvizhi, K.B. Dakshayani, P. Subramanian, Effects of $\alpha$-ketoglutarate on antioxidants and lipid peroxidation products in rats treated with ammonium acetate, Nutrition 18 (2002) 747-750.

39] E. Kosenko, V. Felipo, M.D. Minana, S. Grisolia, Y. Kamisky, Effects of acute hyperammonemia in vivo on oxidative metabolism in nonsynaptic rat brain mitochondria, Metabolic Brain Disease 12 (1997) 69-82.

[40] U. Bohrn, E. Stütz, M. Fleischer, M.J. Schöning, P. Wagner, Eukaryotic cell lines as a sensitive layer for rapid monitoring of carbon monoxide, Physical Status Solidi A 208 (2011) 1345-1350.

[41] M.D. Cheng, B. Malone, J.M.E. Storey, Monitoring cellular responses of engineemitted particles by using a direct air-cell interface deposition technique, Chemosphere 53 (2003) 237-243.

[42] F. Pariselli, M.G. Sacco, D. Rembges, An optimized method for in vitro exposure of human derived lung cells to volatile chemicals, Experimental and Toxicologic Pathology 61 (2009) 33-39.

[43] R. Kubisch, E. Stütz, R. Ehret, S. Drechsler, M. Fleischer, Characterization of eukaryotic cells as the sensitive layer of cell based cytotoxicity sensors, Procedia Chemistry 1 (2009) 730-733.

[44] R. Ehret, W. Baumann, M. Brischwein, A. Schwinde, K. Stegbauer, B. Wolf, Monitoring of cellular behaviour by impedance measurements on 
interdigitated electrode structures, Biosensors and Bioelectronics 12 (1997) 29-41.

[45] W.H. Baumann, M. Lehmann, A. Schwinde, R. Ehret, M. Brischwein, B. Wolf, Microelectronic sensor system for microphysiological application on living cells, Sensors and Actuators B 55 (1999) 77-89.

[46] U. Bohrn, E. Stütz, M. Fleischer, M.J. Schöning, P. Wagner, Real-time detection of CO by eukaryotic cells, Procedia Engineering 5 (2010) 17-20.

[47] U. Bohrn, E. Stütz, M. Fleischer, German Patent DE102010027154 (A1) (2010).

[48] A. Mucha, U. Bohrn, M. Schienle, D. Schmitt-Landsiedel, Sensing cellular adhesion with a CMOS integrated impedance-to-frequency converter, Proceedings of SPIE 8068 (2011) 80680U.

[49] A. Janshoff, A. Kunze, S. Michaelis, V. Heitmann, B. Reiss, J. Wegener, Cell adhesion monitoring using substrate-integrated sensors, Journal of Adhesion Science and Technology 24 (2010) 2079-2104.

[50] A. Janshoff, B. Lorenz, A. Pietuch, T. Fine, M. Tarantola, C. Steinem, J. Wegener, Cell adhesion to ordered pores: consequences for cellular elasticity, Journal of Adhesion Science and Technology 24 (2010) 2287-2300.

[51] A. Wengst, S. Reichl, RPMI 2650 epithelial model and three-dimensional reconstructed human nasal mucosa as in vitro models for nasal permeation studies, European Journal of Pharmaceutics and Biopharmaceutics 74 (2010) 290-297.

[52] F. Pariselli, M.G., Sacco, D. Rembges, Dynamic in vitro exposure of human derived cells to indoor priority pollutants, European Commission- Joint Research Centre, EUR 22285 EN (2006).

[53] E. Bitterle, E. Karg, A. Schroeppel, W.G. Kreyling, A. Tippe, G.A. Ferron, O. Schmid, J. Heyder, K.L. Maier, T. Hofer, Dose-controlled exposure of A549 epithelial cells at the air-liquid interface to airborne ultrafine carbonaceous particles, Chemosphere 65 (2006) 1784-1790.

[54] M. Aufderheide, S. Scheffler, N. Möhle, B. Halter, D. Hochrainer, Analytical in vitro approach for studying cyto- and genotoxic effects of particulate airborne material, Analytical and Bioanalytical Chemistry 401 (2011) 3213-3220.

[55] M. Aufderheide, An efficient approach to study the toxicological effects of complex mixtures, Experimental and Toxicologic Pathology 60 (2008) 163-180.

[56] M. Asakura, T. Sasaki, T. Sugiyama, H. Arito, S. Fukushima, T. Matsushima, An improved system for exposure of cultured mammalian cells to gaseous compounds in the chromosomal aberration assay, Mutation Research 652 (2008) 122-130.

[57] A. Ghaffari, D.H. Neil, A. Ardakani, J. Road, A. Ghahary, C.C. Miller, A direct nitric oxide gas delivery system for bacterial and mammalian cell cultures, Nitric Oxide-Biology and Chemistry 12 (2005) 129-140.

[58] G.S. Samuelsen, Novel culture and exposure system for measurement of effects of airborne pollutants on mammalian cells, Environmental Science and Technology 12 (4) (1978) 426-430.

[59] T. Sandström, Respiratory effects of air pollutants: experimental studies in humans, European Respiratory Journal 8 (1995) 976-995.

[60] C. Pohl, N. Möhle, M. Papritz, D. Steinritz, U. Mohr, S. Hoffmann, C. Kirkpatrick, M. Aufderheide, Prevalidation of the Cultex method: in vitro analysis of the acute toxicity of inhalable fine dusts and nanoparticles after direct exposure of cultivated human cells from the respiratory tract, Toxicology Letters 205 (2011) 60-179.

\section{Biographies}

U. Bohrn graduated in chemistry with a focus on biochemistry at the University of Vienna (Austria) in 2009. He accomplished his diploma thesis on optical biosensors for low cost real-time monitoring of deteriorated meat at the Department of Biochemistry (Vienna/Austria). He is pursuing his $\mathrm{PhD}$ studies at the Chemical Sensors Group of Siemens Corporate Research and Technologies (Munich/Germany) in collaboration with Hasselt University (Belgium) and University of Applied Sciences Aachen (Germany). His work includes research on cell-based sensor systems with applications in the fields of environmental, biomedical, and pharmaceutical research.

E. Stütz graduated in biology at the University of Tübingen with topics in microbiology, immunology, and physiology in 1999. After achieving her PhD 2003 in virology for the identification of cellular markers during the progression of virus-induced skin tumors to maligne skin cancer she obtained a PostDoc position at the Institute of Toxicology at the Helmholtz Center Munich investigating the effect of an anti-epileptic drug on the induction of apoptosis in specific cancer cells. In 2006, she started working in the Chemical Sensors Research Group at Corporate Technology, Siemens, and covers the biological aspects of gas and chemical sensors. Her main focuses there are the biological layers of cell based sensor systems in various applications as well as development of alternative methods in the biomedical field.

K. Fuchs studied physics at the Leibniz University Hanover and achieved her diploma in 2008. After working on several projects concerning quality control and automation of processes at the Chemical Sensors Group of Siemens Corporate Research and Technologies, she started her $\mathrm{PhD}$ thesis in 2010. Subject of the thesis is the research on functional data analysis (FDA) with scalar and categorical responses in collaboration with the Ludwig-Maximilians-University Munich. The focus of research is to enhance and develop FDA methods to enable prediction of various sensor signals, including quality controlling systems based on infrared spectroscopy and cell-based sensor systems.

M. Fleischer heads the Chemical Sensors Research Group of Siemens Corporate Research and Technology. He received the doctoral degree in physics from the Technical University in Munich in 1992, his habilitation in Physics in 1998 and his honorary professorate in 2009 from the Technical University of Budapest. His work includes piezoelectric motors, new types of semiconducting metal oxides, high-temperature electrochemical sensors, tunable laser diode spectroscopy for gas sensing, NIR-spectroscopy for on-line analysis of condensed media, low-power work function based gas sensors and living cell-based sensors.

M.J. Schöning received his diploma degree in electrical engineering (1989) and his $\mathrm{PhD}$ in the field of semiconductor-based microsensors for the detection of ions in liquids (1993), both from the Karlsruhe University of Technology. In 1989, he joined the Institute of Radiochemistry at the Research Centre Karlsruhe. Since 1993, he has been with the Institute of Thin Films and Interfaces (now, Institute of Bio and Nanosystems) at the Research Centre Jülich, and since 1999 he was appointed as full Professor at Aachen University of Applied Sciences, Campus Jülich. Since 2006, he serves as a director of the Institute of Nano- and Biotechnologies (INB) at the Aachen University of Applied Sciences. His main research subjects concern siliconbased chemical and biological sensors, thin-film technologies, solid-state physics, microsystem and nano(bio-)technology.

P. Wagner obtained his PhD in 1994 at Technical University Darmstadt (Germany) in experimental solid state physics with a focus on cuprate superconductors. From 1995 until 2001, he was postdoctoral researcher in the Laboratory of Solid State Physics and Magnetism at Catholic University Leuven (Belgium), where he studied the magneto-transport properties of mixed-valency magnetic oxides. Since 2001, he is a professor of physics at Hasselt University (Belgium) and responsible for the development of label-free readout techniques for DNA-, protein-, and smallmolecule sensors. Patrick Wagner is recipient of a WE Heraeus award, a Marie-Curie Fellowship of the European Union, a Methusalem Grant of the Flemish Government and is past president of the Belgian Physical Society. 